\title{
Pengaruh ekstrak buah naga daging merah (Hylocereus polyrhizus) terhadap berat badan, indeks fagositosis makrofag dan produksi nitrit oksida makrofag (Studi pada mencit BALB/c yang diinfeksi Salmonella typhimurium)
}

\author{
Kusdalinah $^{1}$, Andrew Johan ${ }^{2}$, Noor Wijayahadi ${ }^{3}$
}

\begin{abstract}
Background: Salmonella typhimurium has ability to avoid the phagosome and escape from the trap-free in cytoplasm.Macrophage was activated to phagocyte microbe and produced microbicidal agent nitric oxide (NO).Polyphenolic compounds are proved as an immunomodulatory agent.Hylocereus polyrhizus contains high level of polyphenols and thus increases appetite.

Objective: Proving the effects various doses (6 mg, $12 \mathrm{mg}$, and $24 \mathrm{mg} / 20 \mathrm{~g}$ mice's weight) of Hylocereus polyrhizus extract to increase weight, increase macrophage phagocytosis and NO production of macrophage.

Method:True experiment research for fourteen day on males BALB/c mice, post-test only controlled group design.The treatment groups were a dose of $6 \mathrm{mg} /$ day $(X 1), 12 \mathrm{mg} /$ day $(X 2)$, and $24 \mathrm{mg} /$ day $(X 3)$, whereas the control group (K) was not given the extract of Hylocereus polyrhizus.All treatment and control groups were infected by Salmonella typhimurium intraperitoneally $10^{5} \mathrm{CFU}$ in tenth day.

Results: Weight in the treatment group was higher than the control group ( $p=0.037)$. Index of macrophage phagocytosis was higher in the treatment group compared to the control group but it was not significant $(p=0.154)$. Macrophage NO production was higher in the treatment group compared to the control group but was not significant $(p=0.332)$.

Conclusion: Weight increased significantly.Increasing of macrophage phagocytosis index and macrophage NO production were not significant.
\end{abstract}

Keywords: Hylocereus polyrhizus, Weight, Phagocytosis index, NO

\section{ABSTRAK}

Latar Belakang: Salmonella typhimurium memiliki kemampuan untuk menghindari perangkap fagosom sehingga tetap hidup dalam sitoplasma. Makrofag yang teraktivasi oleh fagosit mikroba akan memproduksi senyawa nitrit oksida (NO) yang merupakan agen mikrobisidal kuat. Senyawa polifenol terbukti sebagai agen imunomodulator. Hylocereus polyrhizus kaya akan senyawa polifenol dan berpotensi memperbaiki nafsu makan.

Tujuan: Membuktikan pengaruh berbagai dosis (6 mg, $12 \mathrm{mg}$, dan $24 \mathrm{mg} /$ berat $20 \mathrm{~g}$ tikus) ekstrak Hylocereus polyrhizus untuk meningkatkan berat badan, meningkatkan fagositosis makrofag dan produksi NO oleh makrofag.

Metode: Penelitian eksperimen selama empat belas hari pada tikus BALB/c dewasa jantan dengan menggunakan post-test post-test only controlled group design. Kelompok perlakuan mendapat dosis 6 mg/hari (X1), 12 mg/hari (X2), dan 24 mg/hari (X3), sementara kelompok control tidak diberikan ekstrak Hylocereus polyrhizus. Semua kelompok baik kelompok perlakuan maupun kontrol diinfeksi oleh Salmonella typhimurium 105. CFU secara intraperitoneal pada hari ke-10.

Hasil: Berat badan pada kelompok perlakuan lebih tinggi dibandingkan kelompok kontrol ( $p=0,037)$. Indeks fagositosis makrofag lebih tinggi pada kelompok perlakuan dibandingkan dengan kelompok kontrol tetapi tidak signifikan ( $p=0,154)$. Produksi NO lebih tinggi pada kelompok perlakuan dibandingkan dengan kelompok kontrol, tetapi tidak signifikan $(p=$ 0,332).

Simpulan: Berat badan meningkat secara signifikan namun peningkatan indeks fagositosis makrofag dan produksi NO tidak signifikan.

Kata kunci: Hylocereus polyrhizus, Berat, indeks Fagositosis, NO

\section{PENDAHULUAN}

Hylocereus polyrhizus merupakan kelompok buah naga merah bahwa khasiat buah naga merah membantu meningkatkan daya tahan tubuh, menambah selera makan, dan bermanfaat bagi metabolisme tubuh manusia. ${ }^{1}$

\footnotetext{
1. Politeknik Kesehatan Jurusan Gizi, Bengkulu

2. Bagian Biokimia Fakultas Kedokteran Universitas Diponegoro

3. Bagian Farmakologi Fakultas Kedokteran Universitas Diponegoro
}

Infeksi saluran cerna pada hewan coba menyebabkan hypophagia (intake makan berkurang), penurunan berat badan (BB). ${ }^{2}$ Penelitian yang melihat efek Hylocereus polyrhizus terhadap peningkatan $\mathrm{BB}$ pada hewan coba terinfeksi sepanjang penelusuran literatur belum pernah dilaporkan, selain itu penelitian mengenai efek fitoterapi yang bersifat imunomodulator dari Hylocereus polyrhizus sejauh ini juga belum pernah dilaporkan. Oleh karena itu penulis tertarik untuk membuktikan efek Hylocerus polyrhizus terhadap peningkatan $\mathrm{BB}$, peningkatan indeks fagositosis makrofag dan produksi NO 
makrofag pada mencit BALB/c yang diinfeksi Salmonella typhimurium.

\section{METODE DAN BAHAN}

Penelitian eksperimental dengan desain post test only controlled group design. ${ }^{3}$ Intervensi pemberian Hylocereus polyrhizus selama 14 hari dengan keluaran adalah peningkatan berat badan, peningkatan indeks fagositosis makrofag dan produksi NO makrofag, Total sampel 28 ekor dibagi menjadi 4 kelompok kecil dengan masing-masing kelompok berjumlah 7 ekor yang ditentukan secara acak sederhana. Kelompok perlakuan dosis $6 \mathrm{mg} / \mathrm{hari}$ (X1), dosis $12 \mathrm{mg} /$ hari (X2), dosis $24 \mathrm{mg} /$ hari (X3), sedangkan kelompok kontrol (K) tidak diberi ekstrak Hylocereus polyrhizus. Semua kelompok perlakuan dan kontrol diinfeksi oleh Salmonella typhimurium $10^{5}$ CFU secara intraperitoneal hari ke-10. Analisis data menggunakan One Way Anova dan alternatifnya Kruskal-Wallis.

Bakteri intraseluler dan termasuk sebagai bakteri gram negatif. Sifat bakteri ini menghindar dari respon imun humoral inang karena mereka tumbuh dalam sel, khususnya sitoplasma fagosit. Bakteri menghindar dari perangkap fagosom sehingga ia tetap bebas dalam sitoplasma dan terhindar dari proses pembunuhan selanjutnya. Untuk menghadapi bakteri jenis ini maka tubuh inang melakukan respon imun selular untuk membunuhnya. ${ }^{4,5}$ Salah satu upaya tubuh untuk mempertahankan diri dari masuknya antigen bakteri yaitu menghancurkan bakteri bersangkutan secara non spesifik dengan proses fagositosis. ${ }^{6}$

Buah naga daging merah (Hylocereus polyrhizus) termasuk buah eksotis yang terkenal mempunyai nilai gizi yang tinggi dan tersedia di seluruh dunia untuk mengatasi masalah kesehatan. ${ }^{7}$ Total polifenol buah naga daging merah lebih tinggi dari pada buah-buahan sumber polifenol lainnya seperti nanas, pepaya, tomat, cheri, dan blueberi. ${ }^{8,9}$ Menurut Al Leong dari Johncola Pitaya Food $R \& D$, organisasi di Malaysia yang meneliti tanaman kaktus.

\section{HASIL}

Studi pendahuluan yang dilakukan dalam penelitian ini adalah pengujian kadar total polifenol pada ekstrak etanol Hylocereus polyrhizus, kadarnya didapatkan sebesar 5,17\%. Sampel awal penelitian berjumlah 28 ekor mencit BALB/c dan tidak ada yang drop out.

\section{Berat badan Mencit}

Tabel 1 menunjukkan rerata $\mathrm{BB}$ akhir semua kelompok perlakuan lebih tinggi dibandingkan dengan kelompok kontrol. Uji normalitas distribusi data BB akhir mencit diperoleh nilai distrisbusi normal.
Berdasarkan Uji One Way Anova diperoleh nilai $\mathrm{p}=0,037$. Hal ini berarti terdapat perbedaan bermakna berat badan kelompok perlakuan dibandingkan dengan kelompok kontrol. Hasil uji Post-Hoc menunjukkan perbedaan berat badan secara bermakna hanya pada kelompok perlakuan 2 dan 3 bila dibandingkan dengan kelompok kontrol, namun antar kelompok perlakuan tidak bermakna.

Observasi kondisi fisik kelompok kontrol pada hari ketiga sampai hari kelima setelah di infeksi Salmonella typhimurium menunjukkan kondisi yang menurun dibandingkan dengan semua

kelompok perlakuan, hal tersebut terlihat dari bulu kasar dan pecah-pecah, aktivitas kurang lincah, serta postur tubuh melengkung. Sementara itu kondisi fisik pada semua kelompok perlakuan menunjukkan hal sebaliknya.

Tabel 1. Hasil analisis One Way Anova BB akhir mencit

\begin{tabular}{lcccc}
\hline & & $\mathrm{n}$ & Mean \pm SD & $p$ \\
\hline & $\mathrm{X} 1$ & 7 & $31,71 \pm 1,79$ & 0,037 \\
BB & $\mathrm{X} 2$ & 7 & $30,43 \pm 1,61$ & \\
akhir & $\mathrm{X} 3$ & 7 & $32,00 \pm 3,21$ & \\
& $\mathrm{~K}$ & 7 & $27,43 \pm 4,54$ & \\
\hline
\end{tabular}

Uji Post Hoc LSD: $\mathrm{X} 1$ vs $\mathrm{K}=0,014 ; \mathrm{X} 2$ vs $\mathrm{K}=0,077$; $\mathrm{X} 3$ vs $\mathrm{K}=0,009$

Ket : X1 = Perlakuan $1(6 \mathrm{mg}) ; X 2=$ Perlakuan $2(12 \mathrm{mg})$; $X 3=$ Perlakuan $3(24 \mathrm{mg}) ; \mathrm{K}=$ Kelompok Kontrol

\section{Indeks Fagositosis Makrofag}

Kemampuan fagositosis makrofag dinyatakan sebagai indeks fagositosis. Tabel 2 menunjukkan rerata indeks fagositosis makrofag pada kelompok perlakuan dosis bertingkat (dari dosis rendah ke dosis tinggi) cenderung mengalami peningkatan, namun pada kelompok kontrol nilai reratanya lebih tinggi dibandingkan dengan kelompok perlakuan.

Uji normalitas distribusi data indeks fagositosis makrofag diperoleh nilai berdistrisbusi normal. Uji Statistik dilanjutkan dengan uji One Way Anova, diperoleh nilai $\mathrm{p}=0,154$. Hal ini berarti tidak ada perbedaan bermakna indeks fagositosis makrofag pada kelompok perlakuan dibandingkan kelompok kontrol.

\section{Produksi NO Makrofag}

Rerata produksi NO makrofag pada kelompok perlakuan dengan dosis bervariasi (dari dosis rendah ke dosis tinggi) cenderung mengalami peningkatan, Nilai reratanya lebih tinggi dibandingkan dengan kelompok kontrol. Uji normalitas data diperoleh nilai berdistrisbusi normal. Uji Statistik dilanjutkan dengan uji One Way Anova, namun berdasarkan Test of 
Tabel 2. Hasil analisis One Way Anova Indeks fagositosis makrofag

\begin{tabular}{|c|c|c|c|c|c|}
\hline \multirow{2}{*}{ Parameter } & \multicolumn{4}{|c|}{ Mean \pm Standar Deviasi (SD) } & \multirow{2}{*}{$p$} \\
\hline & $\mathrm{X} 1$ & $\mathrm{X} 2$ & X3 & $\mathrm{K}$ & \\
\hline $\begin{array}{l}\text { Indeks Fagositosis } \\
\text { makrofag }\end{array}$ & $0,556 \pm 0,261$ & $0,639 \pm 0,235$ & $0,897 \pm 0,448$ & $0,978 \pm 0,519$ & 0,154 \\
\hline
\end{tabular}

Ket : X1=Perlakuan $1(6 \mathrm{mg}) ; X 2=$ Perlakuan $2(12 \mathrm{mg}) ; \mathrm{X} 3=$ Perlakuan 3 (24 mg); K= Kelompok Kontrol

Homogenity of Variances diperoleh nilai $\mathrm{p}<0,05$, yang berarti varians data tidak sama sehingga uji One Way Anova tidak bisa memenuhi syaratuntuk digunakan. Oleh karena itu digunakanuji alternatifnya yaitu uji Kruskal-Wallis. Hasil uji Kruskal-Wallis yakni diperoleh nilai $\mathrm{p}=0,332$. Hal ini berarti tidak ada perbedaan bermakna produksi NO makrofag antara kelompok perlakuan dan kontrol.

\section{PEMBAHASAN}

\section{Berat Badan Mencit}

Rerata BB kelompok perlakuan lebih tinggi dibandingkan dengan kelompok kontrol, Efek Hylocereus polyrhizus secara bermakna meningkatkan BB.Vitamin B2 atau riboflavin pada Hylocereus polyrhizus bermanfaat menambah selera makan. ${ }^{1}$ Riboflavin berfungsi sebagai koenzim flavin mono nukleotida (FMN) dan flavin adenin dinukleotida (FAD) yang berperan dalam metabolisme energi, pernafasan, jaringan dan pemindahan hidrogen, selain itu riboflavin diperlukan untuk pertumbuhan, penglihatan dan kesehatan kulit. ${ }^{10}$ Efek dari vitamin B2 dalam Hylocereus polyrhizus bisa membantu menambah selera makan pada kelompok perlakuan, selain itu vitamin B2 berperan sebagai koenzim dalam proses metabolisme energi. Vitamin B2 inilah yang kemungkinan menyebabkan salah satu terjadinya peningkatan BB pada kelompok perlakuan meskipun kondisi mencit dalam keadaan terinfeksi Salmonella typhimurium.

Infeksi saluran cerna pada hewan coba menyebabkan hypophagia (intake makan berkurang), penurunan berat badan $(\mathrm{BB})^{2}$. Penyakit infeksi secara langsung mempengaruhi status gizi, hiperkatabolisme yang diikuti dengan anoreksia makin memperburuk status gizi ${ }^{11}$. Penurunan BB pada kelompok kontrol pada penelitian ini dikarenakan penyakit infeksi Salmonellosis yang diderita, anoreksia, dan intake makan mencit kemungkinan rendah. Respon fase akut pada keadaan infeksi meliputi gangguan sistemik yang meliputi gangguan syaraf; endokrin; perubahan metabolisme seperti demam, leukositosis, peningkatan kadar hormon, komplemen teraktivasi. Respon fase akut tersebut disertai peningkatan kebutuhan energi dan rendahnya intake makan akan mempengaruhi status gizi. Respon fase akut dipicu oleh aksi sitokin proinflamasi, Interleukin-1 (IL-1), Interleukin 6 (IL-6) dan TNF $\alpha$. Sitokin tersebut bertanggung jawab terhadap perubahan metabolik tubuh maupun serangan patogen terkait dengan sistem imun host. ${ }^{11}$

\section{Indeks Fagositosis Makrofag}

Secara statistik tidak ada perbedaan bermakna indeks fagositosis makrofag antar semua kelompok perlakuan dibandingkan dengan kelompok kontrol. Hasil penelitian ini berbeda dengan penelitian simplisia lainnya seperti pada teh hijau yang bisa meningkatkan kemampuan fagositosis makrofag. Perbedaannya kemungkinan disebabkan jenis senyawa polifenol kelas flavonoid dengan sub kelas flavonol yang ada di dalam Hylocereus polyrhizus berbeda dengan teh hijau, Studi pendahuluan dalam penelitian ini tidak menguji komponen spesifik jenis flavonoid sub kelas flavonol dari Hylocereus polyrhizus, namun hanya menguji kadar total polifenol buah tersebut. Kadar polifenolnya lebih tinggi dibandingkan buah lainnya seperti pisang, nanas, pepaya, tomat, ceri, bluberi. ${ }^{8} 9$ Selain itu mikroba yang digunakan untuk menginduksi respon imunitas pada mencit $\mathrm{BALB} / \mathrm{c}$ juga berbeda.

Pemberian polifenol sebesar $236 \mathrm{mg} / \mathrm{hari}$ dari jus buah (aronia, blueberries, boysenberries) pada manusia sehat selama 14 hari bisa meningkatkan kadar sel $N K{ }^{16}$ Sel NK merupakan sitokin yang memproduksi IFN- $\gamma$ untuk mengaktivasi makrofag. Polifenol yang terkandung di dalam Hylocereus polyrhizus kemungkinan mempunyai efek antioksidan dalam memelihara kemampuan fagositosis makrofag.

Penelitian simplisia lainnya yang mempunyai efek peningkatan kapasitas fagositosis makrofag adalah pemberian ekstrak etanol daun johar (Cassia siamea Lamk.) dengan dosis bervariasi $10 \%(23,78 \mathrm{mg} / 20 \mathrm{~g}$ BB), $20 \%(47,56 \mathrm{mg} / 20 \mathrm{BB})$ dan $40 \%(95,13 \mathrm{mg} / 20 \mathrm{~g}$ BB) pada mencit yang diinjeksi Staphylococcus aureus secara intraperitoneal. Flavonoid yang terkandung dalam ekstrak etanol daun johar memiliki potensi imunomodulator karena flavonoid berpotensi bekerja terhadap limfokin yang dihasilkan oleh sel T sehingga akan merangsang sel-sel fagosit untuk melakukan respon fagositosis. ${ }^{12}$ Hasil penelitian Hylocereus polyrhizus berbeda dengan hasil penelitian Cassia siamea Lamk ini dikarenakan dosis Hylocereus polyrhizus masih terlalu rendah dibandingkan dengan 
dosis bervariasi Cassia siamea Lamk meskipun dosis tertinggi yang digunakan dalam penelitian Hylocereus polyrhizus (24 mg / hari /20 g BB) sudah digunakan dalam dosis terendah Cassia siamea Lamk $(23,78 \mathrm{mg} /$ hari/20 g BB). Mikroba untuk menginduksi respon

Tabel 3. Hasil analisis Kruskal-Wallis Produksi NO makrofag

\begin{tabular}{ccccc}
\hline & & $\mathrm{n}$ & Mean \pm SD & $p$ \\
\hline \multirow{3}{*}{ Produksi NO makrofag } & X1 & 7 & $0,075 \pm 0,127$ & 0,332 \\
& X2 & 7 & $0,103 \pm 0,160$ & \\
& X3 & 7 & $0,180 \pm 0,185$ & \\
\hline
\end{tabular}

Ket : X1 = Perlakuan $1(6 \mathrm{mg}) ; X 2=$ Perlakuan $2(12 \mathrm{mg}) ; X 3=$ Perlakuan $3(24 \mathrm{mg}) ; \mathrm{K}=$ Kelompok Kontrol

imun pada kedua penelitian tersebut juga berbeda. Penggunaan dosis Hylocereus polyrhizus yang lebih tinggi kemungkinkan bisa menghasilkan peningkatan indeks fagositosis makrofag bermakna seperti hasil pada penelitian Cassia siamea Lamk. Bila dosis Hylocereus polyrhizus digunakan lebih tinggi dari 24 $\mathrm{mg} / \mathrm{hari} / 20 \mathrm{~g}$ BB kemungkinan bisa melebihi nilai rerata kelompok kontrol manusia sehat selama 14 hari bisa meningkatkan kadar sel $N K$. Sel NK merupakan sitokin yang memproduksi IFN- $\gamma$ untuk mengaktivasi makrofag. Polifenol yang terkandung di dalam Hylocereus polyrhizus kemungkinan mempunyai efek antioksidan dalam memelihara kemampuan fagositosis makrofag.

\section{Produksi NO Makrofag}

Rerata produksi NO makrofag pada kelompok perlakuan dosis bertingkat lebih tinggi dibandingkan dengan kelompok kontrol, walaupun secara statistik tidak ada perbedaan bermakna produksi NO makrofag antar semua kelompok perlakuan dibandingkan dengan kelompok kontrol. Produksi NO yang meningkat pada semua kelompok perlakuan tersebut sebenarnya telah sesuai dengan hipotesa yang diinginkan, namun secara statistik tidak bermakna.

Total polifenol Hylocereus polyrhizus lebih tinggi dari pada buah-buahan sumber polifenol lainnya seperti nanas, pepaya, tomat, cheri, dan blueberi. ${ }^{9,10}$ Polifenol berfungsi meningkatkan aktivasi ekspresi enzim iNOS. ${ }^{13}$ Polifenol Hylocereus polyrhizus bisa meningkatkan aktivasi ekspresi enzim iNOS sehingga iNOS banyak memproduksi agen mikrobisidal NO. Hasil produksi NO lebih tinggi pada semua kelompok perlakuan dibandingkan dengan kelompok kontrol.

Hasil penelitian simplisia lainnya yang menunjukkan efek peningkatan kemampuan produksi NO makrofag adalah pemberian polifenol teh hijau dengan dosis $(1,5 ; 3$ dan $6 \mathrm{mg}) /$ hari yang diberikan selama 14 hari pada mencit BALB/c diinokulasi Listeria monocytogenes. ${ }^{14,15}$ Ekspresi iNOS secara in vivo terjadi 3 hari setelah infeksi peritoneal. iNOS menghambat replikasi Salmonella. Kelebihan jumlah $\mathrm{NO}$ akan diubah menjadi bentuk peroksinitrit $\left(\mathrm{ONOO}^{-}\right.$
) yang mempunyai efek sitotoksik. $\mathrm{ONOO}^{-}$diperoleh dari reaksi $\mathrm{O}_{2}^{-}$dan $\mathrm{NO}$, berkontribusi awal membunuh Salmonella. ${ }^{16}$ Peningkatan NO makrofag di saluran cerna bisa bersifat sitotoksik terhadap Salmonella tyhpimurium. ${ }^{17}$

Pada penelitian ini tidak dirunut jenis senyawa aktif fenolik yang terkandung dalam Hylocereus polyrhizus, dan tidak dilakukan pemeriksaan killing ability seperti uji hitung kuman di jaringan (hepar, limpa, dan saluran cerna).

\section{SIMPULAN}

Berat badan kelompok perlakuan lebih tinggi dibandingkan dengan kelompok kontrol, secara statistik bermakna $(p=0,037)$. Indeks fagositosis makrofag pada kelompok perlakuan lebih rendah dibandingkan dengan kelompok kontrol, secara statistik tidak bermakna $(p=0,154)$. Produksi NO makrofag pada kelompok perlakuan lebih tinggi dibandingkan dengan kelompok kontrol, namun secara statistik tidak bermakna $(\mathrm{p}=0,332)$.

\section{DAFTAR PUSTAKA}

1. Putra SR. Mengenal seluk beluk buah naga. Buah Naga. Yogyakarta: CV Laksana; 2011.

2. Worthington J, Samuelson LC, Grencis RK, McLaughlin JT. Adaptive Immunity Alters Distinct Host Feeding Pathways during Nematode Induced Inflammation, a Novel Mechanism in Parasite Expulsion.PLOS Pathogens. 2013;Vol. 9: 1-8.

3. Notoatmodjo, S. Metode penelitian eksperimen. Metodologi penelitian kesehatan. Jakarta: Rineka Cipta; 2010.

4. Kresno SB. Respon imun pada infeksi, Imunologi Diagnosis dan Prosedur Laboratorium Edisi 5. Jakarta: FKUI; 2010.

5. Soedarmo SS, Garna H, Hadinegoro SR, Satari HI. Demam Tifoid. Buku ajar Infeksi dan pediatri tropis. Edisi kedua. IDAI; 2008. 
6. Baratawidjaja KG, Rengganis I. Sel-sel Sistem Imun Non spesifik. Imunologi Dasar edisi 9, Jakarta: Balai Penerbit FKUI; 2010.

7. Dembitsky VM, Poovarodom S, Leontowicz H, Leontowicz MV, Trakhtenberg S, Gorinstein S. The multiple nutrition properties of some exotic fruits. Food research international: Elsevier. 2011: 1671-1701.

8. Lako. J, Trenerry CV, Wahlqvist $\mathrm{M}$, Wattanapenpaiboon N, Sotheeswaran S, Premier R. Phytochemical flavonols, carotenoids and the antioxidant properties of a wide selection of Fijian fruit, vegetables and other readily available foods. Food Chemistry J. 2007;101:1727-1741.

9. Lako J, Trenerry VC, Rochfort S. Routine analytical methods for use in South Pacific regional laboratoriesfor determining naturally occurring antioxidants in food. International Food Research Journal. 2008; 15(3): 313-323.

10. Almatsier S. Metabolisme, Transformasi, dan Interaksi. Prinsip Dasar Ilmu Gizi, Edisi ketiga. Jakarta: Gramedia Pustaka Tama; 2003.

11. Pereira PCM. Interaction between infection, nutrition and immunity in tropical medicine. J. Venom. Anim. Toxins incl. Trop; 2003.
12. Kusmardi, Kumala S, Dwitia Wulandari D. Pengaruh pemberian ekstrak etanol daun johar (cassia siamea lamk.) terhadap peningkatan aktivitas dan kapasitas fagositosis sel makrofag. Makara seri Kesehatan UI. 2006; 10(2): 89-93.

13. Amirghofran Z. Herbal medicines for immunosuppression. Iranian Journal of allergy, asthma and immunology. 2012: 111-119.

14. Susilaningsih N, Johan A, Gunardi, Winarto. Pengaruh polifenol teh hijau dan komponen aktifnya terhadap aktifitas makrofag dalam membunuh bakteri. Media Medika Indonesia. 2005; 40 (2): 76-81.

15. Oca MM, Torres SH, Desanctis J, Mata A, Hernandez N, Talamo C. Sceletal muscle inflamation and nitrit oxide in patients with COPD. Eur Respir J. 2005; 390-397.

16. Bub A, Watzl B, Blockhaus M, Briviba K, Liegibel $\mathrm{U}, \mathrm{Mu}$ 'ller $\mathrm{H}$ et al. Fruit juice consumption modulates antioxidative status, immune status and DNA damage. The journal of nutritional biochemistry. 2003; 14 (2): 90-98.

17. Henard CA, Torres AV.Nitrit oxide and Salmonella pathogenesis. 2011; 2(84): 1-11. 